\title{
(5)
}

AL-DZIKRA

Jurnal Studi Ilmu al-Qur'an dan al-Hadits http://ejournal.radenintan.ac.id/index.php/al-dzikra Volume 12, No. 1, Juni Tahun 2018, Halaman 1 - 26

DOI://dx.doi.org/10.24042/al-dzikra.v12i1.2924

\section{PARADIGMA TAFSIR KONTEKSTUAL: UPAYA MEMBUMIKAN NILAI-NILAI AL-QUR'AN}

\author{
Muhammad Hasbiyallah \\ Universitas Islam Negeri Sunan Kalijaga Yogyakarta \\ Hasbimuhammad562@gmail.com
}

\begin{abstract}
Abstrak
Ketertinggalan peradaban umat Islam saat ini melahirkan refleksi diri sebagai upaya mencari jalan menuju kebangkitan. Salah satuny ditempuh dengan melakukan penafsiran ulang teks-teks keislaman (al-Qur'an) sesuai dengan spirit zamannya. Upaya yang dilakukan dengan metode hermeneutika ini biasa disebut dengan kontekstualisasi, melengkapi beberapa pendekatan yang telah ada sebelumnya. Keberagaman pendekatan dan metode yang digunakan berbanding lurus dengan pemahaman yang dihasilkan. Pada dataran ini tidak ada otoritas yang dapat membakukan sebuah model pemahaman. Karena model apapun baik berupa tafsir, ta'wil, exegesis, interpretasi, ataupun penerjemahan terhadap teks al-Qur'an, merupakan wilayah hermeneutika yang sangat terbuka bagi setiap usaha pembaharuan.
\end{abstract}

Kata Kunci: Paradigma, Tafsir, Kontekstual, Nilai, al-Qur'an.

\section{A. Pendahuluan}

Dalam ajaran Islam, pada dasarnya ada dua sumber fundamental, yaitu al-Qur'an dan Sunnah Nabi. Bagi Muslim, al- 
Qur'an adalah wahyu Ilahi. Al-Qur'an merupakan perkataan dari Tuhan dan kehadiran Ilahi pada ruang dan waktu sejarah. Melalui penyelidikan terhadap interpretasi sejarah berdasarkan aspek linguistik dalam al-Qur'an, sebuah usaha dilakukan untuk meningkatkan definisi yang jelas mengenai tafsir dan bagaimana alQur'an itu diinterpretasikan dalam sejarah Islam. ${ }^{1}$

Segala bentuk penjelasan terhadap al-Qur'an adalah upaya menyingkap tabir makna untuk memperoleh pesan dan petunjuk yang terkandung di dalamnya. Varian bentuk dan motivasi penulisannya pun turut mempengaruhi arah dan kecenderungan penafsiran. Ada karya tafsir al-Qur'an yang muncul dengan mengusung perspektif tersendiri, baik dari segi pendekatan maupun latar akademik penulisnya. Di samping itu, ada juga yang muncul sebagai reaksi terhadap karya yang ada sebelumnya, boleh jadi bersifat bantahan ataupun korektif. ${ }^{2}$

Dalam sejarah penafsiran al-Qur'an, Hadis memiliki peranan penting sebagai salah satu sumber tafsir. Hal tersebut juga telah lebih dahulu diungkapkan dalam al-Qur'an bahwa Nabi Muhammad adalah untuk menjelaskan al-Qur'an. Dengan demikian, tafsir kontekstual pertama kali adalah tafsir yang dikemukakan oleh Nabi Muhammad dalam sejumlah kegiatan yang dilakukan dalam membina masyarakat Muslim awal.

Salah satu penggagas tafsir kontekstual adalah Fazlur Rahman. Pemikiran Fazlur Rahman kemudian dikembangkan oleh Abdullah Saeed. Apa yang digagas Saeed lebih mudah dipahami dan dilaksanakan dalam upaya penafsiran al-Qur'an yang disesuaikan pada konteksnya. Secara metodologis dia juga memberikan contoh berbagai penafsiran atau metode yang diungkapkannya. Dapat dilihat dari beberapa poin pemikirannya, Saeed nampak memiliki kemiripan dengan Rahman, khususnya dalam cara pandangnya terhadap al-Qur'an yang secara spesifik

${ }^{1}$ Ferry Muhammadsyah Siregar, "Exploring Methodological Aspect of Linguistic in the Qur'an and its Tafsir" dalam jurnal Religia, Vol. 15 No. 1, April 2012, 1.

2 Syahrullah, "Tarjamah Tafsiriah Terhadap Al-Qur'an: Antara Kontekstualisasi dan Distorsi”, dalam Journal of Qur'an and Hadith Studies, Vol. 2, No. 1, 2013, 43. 
mengaplikasikan analisis double movement-nya Rahman dalam kerangka kerja tafsir kontekstualnya. Selain itu, kontribusi penting Rahman dalam dunia penafsiran yang terkait ethico-legal juga banyak mendapat perhatian dari Saeed. Artinya, dimensi pengembangan tafsir kontekstual Saeed masih belum beranjak dari aspek ethico-legal. ${ }^{3}$

Sementara itu, Ahmad Zaini dalam artikelnya mengkritik model intepretasi yang dilakukan oleh Saeed. Menurutnya, dalam buku Interpreting the Qur'an, Saeed baru mencoba mencari "justifikasi" bahwa menginterpretasikan al-Qur'an mempunyai argumen yang kuat berdasar konteks sosio-historis sehingga tidak perlu keraguan lagi bagi para pemikir untuk melakukan reinterpretasi terhadap teks-teks al-Qur'an sesuai dengan realitas sosial kekinian Buku tersebut akan semakin sempurna jika Saeed memberikan contoh aplikasi bagaimana teks ethico-legal diinterpretasikan dengan menggunakan pendekatan dan metodologi yang ditawarkannya. ${ }^{4}$

\section{B. Pemahaman yang Lebih Luas Mengenai Wahyu}

Kita mungkin dapat membangun pandangan berikutnya mengenai wahyu: Tuhan menyatakan kehendak-Nya (bukan wujudNya) kepada Nabi Muhammad; wahyu kepada Nabi ini terjadi melalui perantara yang dikenal sebagai malaikat Jibril, dalam bahasa Arab, bahasa yang digunakan Nabi; firman Allah terus diterima sebagai wahyu sampai wafatnya Nabi Muhammad, yang setelah itu tidak mungkin ada lagi wahyu baru; antara firman Tuhan dan perkataan Nabi Muhammad jelas berbeda; keberlainan wahyu (yakni, apa yang sepenuhnya diluar diri Nabi Muhammad) harus dipelihara; dan akhirnya, wahyu bebas dari konteks sosio-historis apapun dan abadi.

${ }^{3}$ Muhammad Alfatih Suryadilaga, "Hadis dan Perannya dalam Tafsir Kontekstual Perspektif Abdullah Saeed", dalam Jurnal Mutawatir: Jurnal Keilmuan Tafsir Hadis Vol. 5, No. 2, Desember 2015, 326-327.

${ }^{4}$ Achmad Zaini, "Model Interpretasi Al-Qur'an Abdullah Seed”, dalam jurnal Islamica, Vol. 6, No. 1, September 2011, 34. 
Kebanyakan sarjana muslim yang mengkaji tentang hakikat wahyu hanya melihat wahyu sebagai proses pewahyuan dari Allah kepada Nabi Muhammad. Selama ini hanya ada sedikit penekanan pada konteks sosio-historis bagaimana wahyu diturunkan, atau pada peran Nabi sebagai penerima wahyu yang pasif, dan bahwa wahyu tidak memiliki hubungan dengan konteks sosio-historis. Namun, pandangan yang berikutnya ini adalah pandangan yang lebih luas mengenai konsep wahyu al-Qur'an, yang menghitungkan juga peran Nabi Muhammad beserta konteks sosio-historisnya, sambil tetap mempertahankan sebanyak mungkin pandangan-pandangan muslim tradisional. ${ }^{5}$

\section{Al-Qur'an sebagai Wahyu Ilahi yang Murni}

Warisan besar Rasulullah saw. sebagai utusan Allah swt. adalah al-Qur'an dan Hadis. Dalam kedua warisan tersebut di dalamnya memuat berbagai tuntunan yang dapat dijadikan sebagai pedoman dalam kehidupan keseharian baik secara individu, maupun sosial. $^{6}$

Al-Qur'an menyangkal bahwa al-Qur'an berisi perkataan atau ide-ide Nabi atau manusia lainnya. Al-Qur'an juga menegaskan bahwa wahyu, dalam bentuk bahasa Arab terakhirnya, datang langsung dari Allah, tanpa adanya kemungkinan tentang kesalahan yang disebabkan manusia atau ketidak akuratan. Misalnya alQur'an menyatakan:

Dan tidak mungkin al-Quran ini dibuat-buat oleh selain Allah; tetapi (al-Quran) membenarkan (kitab-kitab) yang sebelumnya dan menjelaskan hukum-hukum yang telah ditetapkannya,tidak ada keraguan di dalamnya, (diturunkan) dari Tuhan seluruh alam. Apakah pantas mereka mengatakan dia (Muhammad) yang telah membuatbuatnya? Katakanlah, "Buatlah sebuah surah yang semisal dengan surah (al-Quran), dan ajaklah siapa saja di antara kamu orang yang

5 Abdullah Saeed, "Pengantar Studi Al-Qur'an", terj. Shulkhah dan Sahiron Syamsuddin (Yogyakarta: Baitul Hikmah Press, 2016), hlm. 48-49

6 Muhammad Alfatih Suryadilaga, "Kontekstualisasi Hadis dalam Kehidupan Berbangsa dan Berbudaya", dalam Jurnal Kalam, Vol. 11 No. 1, Juni 2017, 216. 
mampu (membuatnya) selain Allah, jika kamu orang-orang yang benar."

Seiring dengan tantangan semacam itu, al-Qur'an juga berpendapat seandainya al-Qur'an berasal dari sumber selain Allah, mereka akan menemukan banyak kontradiksi dan inkonsistensi di dalamnya. Terkait dengan hal ini adalah bahwa tidak ada hubungannya Nabi dengan sumber wahyu. Fakta ini ditunjukkan dalam al-Qur'an sendiri dan sering ditekankan oleh Nabi. Seperti yang Fazlur Rahman katakan: "Nabi sendiri selalu sadar bahwa kenabiannya bukan buatan sendiri dan bahkan kapasitas alamiahnya tidak mampu menghasilkan wahyu, yang semata-mata merupakan rahmat Allah". Menurut Rahman, keterpisahan ini lebih lanjut diilustrasikan dengan contoh dimana al-Qur'an diberikan kepada Nabi secara langsung. Misalnya, Nabi disindir dalam al-Qur'an karena menggerakkan lidahnya ketika menghadapi wahyu yang diterimanya dari Allah:

Jangan engkau (Muhammad) gerakkan lidahmu (untuk membaca alQuran) karena hendak cepat-cepat (menguasai)nya. Sesungguhnya Kami yang akan mengumpulkannya (di dadamu) dan membacakannya. Apabila Kami telah selesai membacakannya maka ikutilah bacaannya itu. Kemudian sesungguhnya Kami yang akan Menjelaskannya. ${ }^{7}$

\section{Memahami Teks Al-Qur'an}

Sebagai firman Allah SWT yang diperuntukkan kepada manusia, al-Quran tidak turun dalam ruang yang hampa budaya, melainkan lahir dalam ruang-waktu yang sarat budaya. Oleh sebab itu, teks al-Quran seperti teks-teks lainnya adalah teks historis. Dalam konteks inilah, al-Quran telah beralih eksistensi, dari teks Ilahi menjadi pemahaman atau teks manusia. ${ }^{8}$

Dalam bahasan umum, terdapat tiga sumber pengetahuan: akal, indera, dan intuisi. Ketiganya membentuk formasi yang

${ }^{7}$ Ibid., 44-45.

${ }^{8}$ Fathul Mufid, "Pendekatan Filsafat Hermeneutika dalam Penafsiran Al-Qur'an: Transformasi Global Tafsir al-Quran”, dalam web: http://download.portalgaruda.org/article.php?article=116305\&val=5267, diakses pada tanggal 14 Desember 2017. 
paralel. Namun dalam Islam paralelitas itu tidak ditemukan. Paralelitas tidak ada, kecuali hanya hirarki. Ketiganya malah dikategorikan sumber sekunder. Sumber utamanya adalah teks, yakni al-Qur'an. Al-Qur'an memiliki validitas paling shahih dibanding sumber lainnya. Sifatnya otoritatif, karena agama Islam adalah agama wahyu. Di sini wahyu sebagai yang lebih tinggi, sedangkan akal, apalagi indra dan intuisi, tidak lebih dari sekadar pendukung atau pelengkap dari wahyu. Karena itu, ketika berbicara tentang epistemologi Islam, pembicaraan awal tertuju pada pola hubungan antara wahyu dan akal. Dan sekali lagi, hubungan keduanya bukanlah hubungan yang setara atau sebanding. Wahyu berfungsi sebagai pokok (ashl), sedangkan akal adalah cabang (furu'). Dan cabang bagaimanapun harus tunduk pada pokok. Dalam kategorisasi Abid al-Jabiri tentang struktur nalar Arab Islam, prosedur cabang yang tunduk pada pokok disebut epistemologi bayani, berlawanan dengan burhani (mengandalkan akal) dan irfani (intuisi). ${ }^{9}$

Teks al-Qur'an sendiri sangat debatable, bahkan multi interpretatif. Para pembacanya selalu saja ingin mengutip dan menafsirkan, karena itu lahirlah berbagai komentar, beragam buku, dan juga beragam sanjungan dan hujatan. Pada saat yang sama, di ujung sudut yang lain selalu saja ada keinginan untuk kembali dan berlindung di bawah naungannya. Abdullah Darraz sebagaimana dikutip Quraish Shihab, menulis sebagai berikut:

“Apabila anda membaca al-Qur'an, maknanya akan jelas di hadapan anda. Tetapi apabila anda membacanya sekali lagi, akan anda temukan pula makna-makna lain yang berbeda dengan makna-makna sebelumnya. Demikian seterusnya, sampai-sampai anda (dapat) menemukan kalimat atau kata yang mempunyai arti bermacammacam, semuanya benar atau mungkin benar. (Ayat-ayat al-Qur'an) bagaikan intan, setiap sudut memancarkan cahaya yang berbeda dengan apa yang terpancar dari sudut-sudut lain. Dan tidak mustahil,

${ }^{9}$ Lihat Buwaihi, "Fazlur Rahman dan Pembaharuan Metodologi Tafsir A-Qur'an”, dalam jurnal Media Akademika, Vol. 28, No. 1, Januari 2013, 143 144. 
jika anda dipersilahkan orang lain memandangnya maka ia akan melihat lebih banyak ketimbang yang anda lihat."10

\section{E. Memahami Hakikat Tafsir}

Wajdi Khalid dalam artikelnya Urgensi Tafsir Dalam Memahami Al-Qur'an menjelaskan bahwa tafsir termasuk disiplin ilmu islam yang paling mulia dan luas cakupannya. Paling mulia, karena kemulian sebuah ilmu itu berkaitan dengan materi yang dipelajarinya, sedangkan tafsir membahas firman-firman Allah. Dikatakan paling luas cakupannya, karena seorang ahli tafsir membahas berbagai macam disiplin ilmu, dia terkadang membahas akidah, fikih, dan akhlak. Di samping itu, tidak mungkin seseorang dapat memetik pelajaran dari ayat-ayat al-Qur'an, kecuali dengan mengetahui makna-maknanya. ${ }^{11}$

Rasulullah Saw. merupakan manusia pertama yang melakukan penafsiran terhadap Al-Qur'an. Diikuti kemudian oleh para sahabat dan generasi berikutnya. Penafsiran mereka terekam dalam riwayat-riwayat yang sampai pada generasi setelahnya. Penafsiran terus berkembang seiring semakin kompleksnya persoalan yang dihadapi umat Islam kala itu. Seiring berjalannya waktu, penafsiran semakin beragam dengan corak dan metodenya masing-masing; sebagian mempertahankan riwayat yang diterima dari generasi awal Islam (Nabi, Shahabat dan generasi setelahnya), sedangkan sebagian yang lain melakukan inovasi dan improvisasi. Mereka sudah berani menggunakan nalar. Ironisnya, dua golongan ini kemudian secara otomatis membentuk kelompok terpisah dan bahkan seperti terjebak dalam klaim kebenaran masing-masing. ${ }^{12}$

10 Sa'dullah Affandy, "Menyoal Status Agama-agama Pra-Islam", (Bandung: PT. Mizan Pustaka, 2015) hlm. 103-104.

${ }^{11}$ Wajdi Khalid, “Urgensi Tafsir Dalam Memahami Al-Qur'an”, dalam web: http://www.pesantrenalirsyad.Org/ urgensi-tafsir-dalam-memahami-alquran/, diakses pada tanggal 12 Desember 2017.

12 Miski, “Hermeneutika Al-Qur'an Kontemporer: Telaah Atas Hermeneutika Muhammad Al-Gazali Dalam Nahw Tafsir Maudu'i liSuwar alQur'an al-Karim”, dalam jurnal Hermeneutik, Vol. 9, No. 2, Desember 2015, 432-433. 
Berbicara soal penafsiran, hampir dipastikan terdapat pengaruh subjektif dari kalangan mufassir. Hal itu terjadi sebab faktor tingkat pemahaman para mufassir dalam memaknai teks alQur'an, penguasaan disiplin keilmuannya, latar belakang sosial yang melingkupinya, dan tentunya perbedaan zaman sangat memegaruhi pemikirannya. Fenomena tersebut menurut Amina Wadud membuktikan bahwa tidak ada metode penafsiran yang benar-benar objektif. Yang sebenarnya terjadi adalah ungkapan subjektif seorang mufassir, sehingga dapat dipastikan penafsiran tersebut tidak dapat mencerminkan kemauan teks itu sendiri.

Senada dengan Wadud, Nasr Hamid Abu Zaid menegaskan bahwa kondisi sosial yang membentuk seorang mufassir akan sangat berpengaruh dan tidak dapat dipisahkan atas pemahamannya terhadap teks keagamaan. Oleh karenanya, menurut Farid Essack, faktor pre-understanding (pra-pemahaman) yang melingkupi pemahaman sejarah mufassir sangat dominan dalam memengaruhi pemahaman mereka terhadap al-Qur'an. Hal yang sama dinyatakan Yunus Hasan Abidu yang mengungkapkan bahwa produk penafsiran dari satu generasi ke generasi penerusnya cenderung berbeda, setidaknya dalam hal corak dan karakteristik. Ini membuktikan ada faktor yang memengaruhinya seperti kondisi sosio-historis dimana seorang mufassir tinggal, begitu juga situasi politik yang melingkupinya, sedikit banyak dapat memberikan andil dalam mewarnai penafsirannya. Pendapat hampir sama sebagaimana dinyatakan Syaikh Muhammad Husain al-Dzahabi (1914-1977). Menurutnya, kecenderungan tiap-tiap mufassir dengan pengetahuan yang dikuasainya, ideologi, dan madzhabnya berpengaruh terhadap perbedaan mereka menafsirkan al-Qur'an, terutama ketika dalam tahap kodifikasi. ${ }^{13}$

Meskipun bukan berarti terjebak pada subjektivisme dan relativisme total. Menolak objektivitas total bukan berarti penafsiran menjadi arena bebas bagi subjektivitas dan relativitas, dalam artian penafsir bisa mendekati teks dan menafsirkannya sesuka dan sekehendaknya.

${ }^{13}$ Sa'dullah Affandy, "Menyoal Status Agama-agama Pra-Islam”, hlm. 102-103. 
Berangkat dari paradigma pemikiran di atas, dapat disimpulkan bahwa, secara ontologis, hakikat tafsir bermuara pada dua aspek yaitu:

Pertama, tafsir sebagai proses, berimplikasi pada sebuah penafsiran yang tidak mengenal kata final dan harus dilakukan secara terus menerus. Artinya bahwa sebuah kerja penafsiran harus senantiasa berlanjut dan tidak boleh berhenti, melainkan harus selalu berproses seiring dan sejalan dengan tuntutan dan kebutuhan zaman. Maka dari itu, al-Qur'an harus ditafsir secara terus-menerus demi kepentingan manusia, sehingga tidak kehilangan relevansinya dengan perkembangan zaman. Ini juga berarti bahwa, meskipun selama ini telah banyak berbagai produk kitab tafsir dengan segala kebesarannya, tidak perlu ada sakralitas terhadapnya. Kitab-kitab tersebut tidak lebih dari sekadar refleksi terhadap kondisi-kondisi yang dihadapi oleh sang mufasir ketika itu. Maka, sakralitas terhadap tafsir al-Qur'an hanya akan menyebabkan dinamika pemikiran umat Islam mengalami stagnasi, karena perbuatan tersebut termasuk ke dalam "syirik intelektual".

Kedua, tafsir sebagai produk, berimplikasi bahwa al-Qur'an adalah pedoman hidup yang harus dikaji dan ditafsiri sebagai petunjuk hidup umat manusia. Hasil atau produk pemikiran ini kemudian dikenal sebagai kitab tafsir. Yaitu sebuah kitab yang menghimpun hasil ijtihad seseorang berupa keterangan-keterangan terhadap makna-makna al-Qur'an yang sifatnya asing dan sulit dipahami. Penafsirannya pun dilakukan dengan cara menggunakan seperangkat alat dan kemampuan ilmu pengetahuan yang dimiliki oleh setiap mufasir. Sehingga tafsir cenderung sebagai manifestasi kebutuhan manusia yang dilakukan dengan cara mendialektikakan teks (al-Qur'an), pembaca (umat manusia), dan realitas (konteks kehidupan). Maka, betapapun teks yang ditafsirkan adalah suci, tetapi hasil interpretasinya sudah tidak suci lagi. Karena telah masuk ke dalam "disket pemikiran" manusia, sehingga teks suci tersebut tereduksi untuk dapat masuk ke dalamnya, kemudian bercampur dengan usaha pemikiran manusia, sehingga hasilnya tidak lagi "asli ilāhiyyah" atau bersifat insāniyyah. Sebagaimana keterbatasan dan 
kerelativitasan manusia, maka apapun yang diproduksi oleh manusia menjadi relatif dan terbatas. ${ }^{14}$

Dalam catatan Abdullah Saeed, tafsir kontekstual Umar menjadi salah satu referensi penting bagaimana al-Qur'an ditafsirkan pada masa awal. Umar bin Khattab menafsir ulang aturan-aturan dan perintah dalam al-Qur'an dengan mempertimbangkan konteks. Bagi Umar, al-Qur'an merupakan teks yang hidup, dan petunjuknya membutuhkan penafsiran yang sesuai dengan spiritnya sehingga tetap sesuai dengan lingkungan yang berubah. Gagasan-gagasan dalam tafsir kontektual yang dilakukan Umar, semisal kepentingan umum, properti publik, pemerataan dan keadilan, serta kesadaran akan konteks yang berubah menjadi acuan tafsir kontekstual masa kini. ${ }^{15}$

\section{F. Penafsiran Kontekstualis}

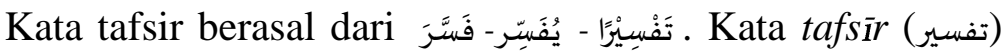
adalah bentuk masdar dari fassara - yufassiru (فَسََّرَ يُفَسِّرَ) yang mengandung pengertian "penjelasan" dan "keterangan”. Kata tafsìr berarti menerangkan sesuatu yang masih samar serta menyingkap sesuatu yang tertutup. Secara etimologis, tafsïr digunakan untuk menunjukkan maksud menjelaskan, mengungkapkan, dan menerangkan suatu masalah yang masih kabur, samar dan belum jelas. Di dalam al-Qur'an, kata tafsĩr disebut satu kali:

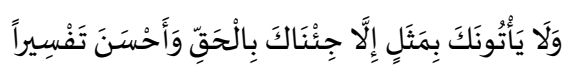

"Tidaklah orang-orang kafir itu datang kepadamu (membawa) sesuatu yang ganjil, melainkan Kami datangkan kepadamu suatu yang benar dan yang paling baik penjelasanny." (QS. Al-Furqan: 33).

Kata tafsìr di dalam ayat tersebut berkaitan dengan alQur'an yang membawa kebenaran dan penjelasan yang paling baik. Pemahaman terhadap makna al-Qur'an, selain kata tafsir digunakan

${ }^{14}$ Mk. Ridwan, “Tradisi Kritik Tafsir: Diskursus Kritisisme Penafsiran dalam Wacana Qur'anic Studies”, dalam jurnal Theologia, Vol.28, No.1, Juni 2017, 64-67.

${ }^{15}$ Abdullah Saeed, "Al-Qur'an Abad 21 Tafsir Kontekstual", (Bandung: PT. Mizan Pustaka, 2016), hlm. 67-68. 


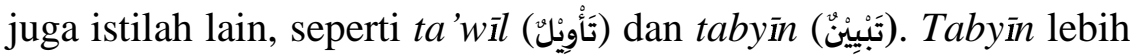
dikhususkan pada fungsi Nabi yang mendapat tugas menjelaskan maksud firman-firman Allah SWT. Istilah tersebut diisyaratkan dalam firman Allah SWT:

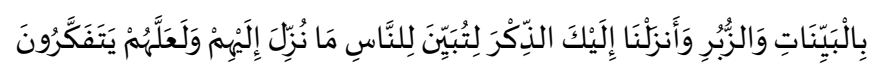

"Keterangan-keterangan (mukjizat) dan kitab-kitab. Dan Kami turunkan kepadamu al-Quran, agar kamu menerangkan pada umat manusia apa yang telah diturunkan kepada mereka dan supaya mereka memikirkan." (QS. An-Nahl: 44).

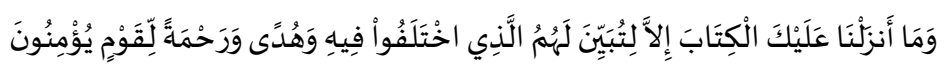

"Dan Kami tidak menurunkan kepadamu al-Kitab (al-Quran) ini, melainkan agar kamu dapat menjelaskan kepada mereka apa yang mereka perselisihkan itu dan menjadi petunjuk dan rahmat bagi kaum yang beriman." (QS. An-Nahl: 64).

Al-Qur'an juga menggunakan istilah ta'wil, firman Allah:

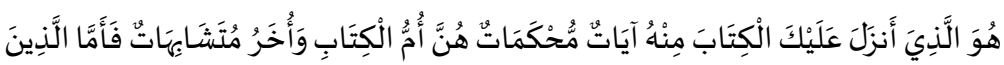

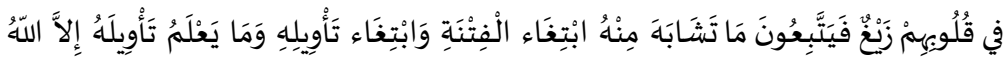

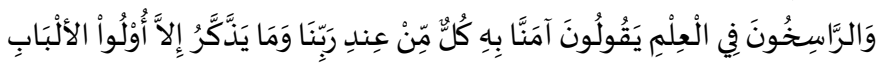

"Dia-lah yang menurunkan al-Kitab (al-Quran) kepada kamu. Diantara-(isi)-nya ada ayat-ayat yang muhkamat. Itulah pokokpokok isi al-Qur'an dan yang lain (ayat-ayat) mutasyabihat. Adapun orang-orang yang dalam hatinya condong kepada kesesatan, maka mereka mengikuti sebahagian ayat-ayat yang mutasyabihat daripadanya untuk menimbulkan fitnah untuk mencaricari ta'wilnya, Padahal tidak ada yang mengetahui ta'wilnya melainkan Allah. Dan orang-orang yang mendalam ilmunya berkata: "Kami beriman kepada ayat-ayat yang mutasyabihat, semuanya itu dari sisi Tuhan kami." Dan tidak dapat mengambil pelajaran (daripadanya) melainkan orang-orang yang berakal.” (QS. Ali Imran: 7).

Adapun pengertian tafsir secara terminologis adalah mengkaji, memahami, dan menjelaskan al-Qur'an baik dari segi kedalaman makna, isi dan maksud yang dikehendaki oleh Allah SWT sebatas maksimal kemampuan manusia. ${ }^{16}$

${ }^{16}$ Anhar Ansyory, "Pengantar Ulumul Qur'an" (Yogyakarta: Lembaga Pengembangan Studi Islam Universitas Ahmad Dahlan Yogyakarta, 2012) h. 8589. 
Kata "kontekstual" berasal dari "konteks" yang dalam Kamus Besar Bahasa Indonesia mengandung dua arti: 1) bagian sesuatu uraian atau kalimat yang dapat mendukung atau menambah kejelasan makna; 2) situasi yang ada hubungan dengan suatu kejadian. Kedua arti ini dapat digunakan karena tidak terlepas istilah dalam kajian pemahaman tafsir kontekstual.

Dari sini pemahaman kontekstual atas al-Qur'an adalah memahami makna ayat-ayat al-Qur'an dengan memperhatikan dan mengkaji keterkaitannya dengan peristiwa atau situasi yang melatarbelakangi turunnya ayat-ayat tersebut, atau dengan kata lain, dengan memperhatikan dan mengkaji konteksnya. Dengan demikian asbab an-nuzul dalam kajian kontekstual dimaksud merupak an bagian yang paling penting. Tetapi kajian yang lebih luas tentang pemahaman kontekstual tidak hanya terbatas pada asbab an-nuzul dalam arti khusus seperti yang biasa dipahami, tetapi lebih luas dari itu meliputi: konteks sosio-historis di mana asbab an-nuzul merupakan bagian darinya. Dengan demikian, pemahaman kontekstual atas ayat-ayat al-Qur'an berarti memahami al-Qur'an berdasarkan kaitannya dengan peristiwa-peristiwa dan situasi ketika ayat-ayat diturunkan, dan kepada siapa serta tujuannya apa ayat tersebut diturunkan.

Untuk itulah al-Qur'an berusaha didialogkan dengan realita zaman sekarang, melalui studi kontekstualitas al-Qur'an. Sedangkan makna yang lebih luas lagi, studi tentang kontekstual alQur'an adalah studi tentang peradaban yang didasarkan pada pendekatan sosio-historis. Adapun pemahaman sosio-historis dalam pendekatan kontekstual adalah pendekatan yang menekankan pentingnya memahami kondisi-kondisi aktual ketika al-Qur'an dalam rangka menafsirkan pernyataan legal dan sosial ekonominya. Atau dengan kata lain, memahami al-Qur'an dalam konteks kesejarahan dan harfiyah, lalu memproyeksikannya kepada situasi masa kini kemudian membawa fenomena-fenomena sosial ke dalam naungan-naungan tujuan al-Qur'an.

Aplikasi pendekatan kesejarahan ini menekankan pentingnya perbedaan antar tujuan atau "ideal moral" al-Qur'an dengan ketentuan legal spesifiknya. Ideal moral yang dituju al- 
Qur'an lebih pantas diterapkan ketimbang ketentuan legal spesifiknya. Jadi dalam kasus seperti perbudakan yang dituju alQur'an adalah emansipasi budak. Sementara penerimaan al-Qur'an terhadap pranata tersebut secara legal, dikarenakan kemustahilan untuk menghapuskan seketika.

Pendekatan sejarah tersebut tidak bisa lepas dari asbab annuzul ayat al-Qur'an yang biasanya -walau tidak seluruhnyabersumber dari Sunnah, atsar ataupun dari tabi'in. Jadi, secara metodologis teknik ini termasuk kedalam metode tafsir bi alma'tsur. Hubungan teks dan konteks bersifat dialektis; teks menciptakan konteks, persis sebagaimana konteks menciptakan teks; sedangkan makna timbul dari keduanya. Upaya ke arah penafsiran kontekstual terhadap teks-teks al-Qur'an pertama-tama harus dimulai dengan menempatkan prinsip ketuhanan Tauhid. Di sinilah, maka ayat-ayat al-Qur'an yang bermakna pesan-pesan yang bersifat universal ini harus menjadi dasar bagi seluruh cara pandang penafsiran kita terhadap teks-teks atau ayat-ayat al-Qur'an. ${ }^{17}$

Tafsir kontekstual -secara sederhana- adalah kegiatan untuk mengeksplansi firman Allah SWT dengan memperhatikan indikasiindikasi dari susunan bahasa dan keterkaitan kata demi katayang tersusun dalam kalimat serta memperhatikan pula penggunaan susunan bahasa itu oleh masyarakat, sesuai dengan dimensi ruang dan waktu. Sehingga tafsir jenis ii memiliki aneka ragam konteks, baik konteks bahasa, konteks waktu, konteks tempat, maupun konteks sosial budaya. Dengan demikian, paling tidak terdapat dua hal yang perlu ditekankan dalam proses tafsir kontekstual, yaitu: aspek kebahasaan, dan aspek ruang dan waktu; baik masa terciptanya teks pada pada suayu masyarakat atau lingkungan tertentu, maupun masa sekarang yang menjadi ruang dan waktu dari penafsir suatu teks. ${ }^{18}$

17 Mustaqimah, "Urgensi Tafsir Kontekstual dalam Penafsiran AlQur'an”, dalam Jurnal Farabi No. 12, No. 1, Juni 2015, h. 144-145.

${ }^{18}$ Mohammad Andi Rosa, "Prinsip Dasar dan Ragam Penafsiran Kontekstual”, dalam Jurnal Holistic Al-Hadis, Vol. 1, No. 2, Juli-Desember 2015, h. 185-186. 


\section{G. Paradigma Tafsir Kontekstual}

Yang dimaksud dengan "kontekstual" disini adalah sebuah kecenderungan dalam menafsirkan al-Qur' an tidak hanya bertumpu pada makna lahir teks saja, tetapi juga melihat segi sosio-historis di mana, kapan dan mengapa suatu ayat diturunkan.

Di antara ciri penafsiran kontekstual adalah model tafsir ini menekankan konteks sosio-historis dalam proses penafsirannya. Ciri lainnya, tafsir ini lebih melihat nilai etis dari ketetapan legal (the ethico-legal content) al-Qur'an, daripada makna literalnya. Berbeda dengan tafsir tekstual yang secara ketat mendasarkan pemaknaan teks pada unsur linguistik dan keterangan riwayat, tafsir kontekstual melihat bahwa unsur politik, sosial, sejarah, budaya, dan ekonomi adalah hal-hal penting dalam upaya memahami makna teks (pada saat diturunkan, pada saat teks itu ditafsirkan, dan kemudian pada saat diterapkan). Berbeda dengan tafsir tradisionalis, yang cenderung teologis-filosofis, tafsir kontekstual lebih cenderung sosiologis, aksiologis, dan antropologis, karena tujuannya yang ingin memenuhi kebutuhan kaum Muslim di era kontemporer sekarang ini. ${ }^{19}$

Elemen-elemen pemahaman keagamaan yang kontekstual, sebenarnya telah ada sejak era para sahabat. Elemen-elemen tersebut selanjutnya berkembang hingga kini dengan segenap varian dan pasang surutnya. Dari waktu ke waktu, para ulama telah menyumbangkan pemikirannya untuk semakin mematangkan dan menyempurnakan pola pemahaman tersebut. Ditinjau dari sisi manhaj berpikir, tafsir keagamaan yang bercorak kontekstual didasarkan pada sejumlah paradigma:

Pertama, karakteristik misi risalah Islam sebagaimana telah dicontohkan pada masa Nabi, harus dipertahankan. Nilai-nilai dasar keislaman seperti persaudaraan, keadilan, solidaritas sosial dan empati, harus senantiasa dijunjung tinggi.

Paradigma kedua, setiap lingkungan masyarakat memiliki nilai-nilai luhur dan kearifan yang perlu dilestarikan. Kedatangan

${ }^{19}$ Cucu Surahman, "Tafsir Kontekstual JIL: Telaah atas Konsep Syariat dan Hudud," dalam Journal of Qur'an and Hadith Studies, Vol. 2, No. 1, 2012, h. 6566. 
Islam bukan untuk merombak total semua yang ada sebelumnya. Kedatangan Islam bertujuan untuk mengakomodir hal-hal yang sudah baik, menyempurnakan hal-hal yang belum sempurna, serta mengoreksi dan meluruskan bagian-bagian tertentu yang dipandang masih keliru. Dengan menjaga keseimbangan antara perspektif perubahan dan kesinambungan (change and continuity), maka ikhtiar pembumian ajaran Islam diharapkan berproses secara damai, beradab dan berkelanjutan, sejalan dengan denyut perkembangan sosial.

Paradigma ketiga, inti ajaran Islam adalah akidah dan akhlak, yang selanjutnya diimplementasikan lewat penerapan syariah. Dengan kata lain, syariah sesungguhnya merupakan "instrumen" untuk menegakkan akidah dan akhlak yang Islami secara komprehensif. Semua pemikiran syariah, strategi dan langkah penerapannya harus didesain dengan spirit dan landasan fundamentalnya. Oleh karena itu, semua paham dan cara-cara yang ditempuh untuk memperjuangkan Islam yang bertentangan dengan kemuliaan martabat kemanusiaan harus dihindari, misalnya pemaksaan, intimidasi, kekerasan, dan lain-lain. ${ }^{20}$

\section{H. Komponen-komponen Dasar Pendekatan Kontekstual}

Upaya perumusan kembali nilai al-Qur'an untuk memenuhi tantangan dan kebutuhan yang berbeda-beda di setiap masa, maka perhatian yang mendalam hendaklah diarahkan kepada empat komponen pokok yang saling terkait erat. Adapun empat komponen tersebut adalah sebagai berikut:

Pertama, konteks literer al-Qur'an. maksudnya adalah konteks di mana suatu tema atau istilah tertentu muncul di dalam alQur'an, mencakup ayat-ayat sebelum dan sesudah tema atau terma itu yang merupakan konteks langsungnya serta rujukan silang kepada konteks-konteks relevan dalam surat-surat lain. Pada batasbatas tertentu, konteks literer juga mencakup penelusuran keragaman tradisi teks (rasm) dan bacaan al-Qur'an (qira'ah) yang

${ }^{20}$ Ahmad Faisal, "Tafsir Kontekstual Berwawasan Gender (Eksplorasi, Kritik dan Rekonstruksi) ”, dalam jurnal Al-Ulum: Jurnal Studi-Studi Islam, Vol. 13 No. 2, Desember 2013, h. 473-476. 
relevan dengan ayat-ayat yang dicobapahami untuk mendapatkan pemahaman yang lebih mendalam tentangnya.

Kedua, Konteks historis al-Qur'an yang merupakan latar kesejarahan al-Qur'an baik yang bersifat makro maupun mikro. Konteks historis makro adalah latar kesejarahan tidak langsung atau mileu yang berupa situasi masyarakat, agama, adat-istiadat, pranatapranata, relasi-relasi politik, dan bahkan kehidupan secara menyeluruh di Arabia sampai kepada kehidupan Nabi Muhammad saw sendiri, terutama Makkah dan Madinah menjelang dan pada saat pewahyuan al-Qur'an.

Sedangkan konteks historis mikro adalah latar kesejarahan langsung teks-teks spesifik al-Qur'an yang direkam dalam apa-apa yang disebut mawathin al-nuzul (tempat-tempat turun), sya'n alnuzul (situasi turun) dan asbab al-nuzul (sebab-sebab turun) alQur'an.

Ketiga, konteks kronologis al-Qur'an. Maksudnya kronologis pewahyuan bagian-bagian al-Qur'an tentang suatu tema atau istilah tertentu yang akan memperlihatkan bagaimana tema tersebut berkembang dalam bentangan pewahyuan al-Qur'an selama lebih kurang 23 tahun seirama dengan perkembangan misi kenabian Muhammad saw dan komunitas Muslim. Di dalam tradisi 'Ulum al-Qur'an, aspek kronologis ini setidaknya telah dicakup oleh ilmu tawarikh an-nuzul, ilmu al-makki wa al-madani dan ilmu al-naskh.

Keempat, konteks spasio-temporal yang merupakan konteks ruang dan waktu yang menjadi lahan pengimplementasian gagasangagasan al-Qur'an. Di sini, situasi kontemporer harus diteliti secara cermat terkait berbagai unsur komponennya, sehingga dapat dinilai dan diubah sejauh diperlukan, serta dapat dideterminasi prioritasprioritas baru untuk implementasi nilai-nilai Al-Qur'an secara segar dan bermakna.

Dapat dilihat bahwa konteks literer al-Qur'an berada di wilayah sastra dan kebahasaan; konteks historis al-Qur'an berada di wilayah sosiologi, antropologi, dan geografi; konteks kronologis alQur'an berada di wilayah sejarah dan arkeologi; konteks spasiotemporal dewasa ini tetap sangat bergantung pada kualitas kajian- 
kajian keilmuan, kemasyarakatan, dan kebudayaan dalam artinya yang lebih spesifik. ${ }^{21}$

\section{Metode dan Aplikasi Tafsir Kontekstual}

M. Subhan Zamzami dalam artikelnnya yang berjudul Tafsir Kontekstual, menyatakan bahwa sebagaimana teori-teori fikih dan tafsir yang diformulasikan dengan cara menelaah karya-karya fikih dan tafsir yang ada, metode dan aplikasi tafsir kontekstual juga bisa disimpulkan atau dirinci satu persatu sesuai dengan urutannya sebagai berikut:

Pertama, menguasai dengan baik sejarah manusia terutama sejarah orang-orang Arab pra-Islam, baik secara bahasa, sosial, politik, dan ekonomi sebagai modal awal proses penafsiran kontekstual. Sebab selain al-Qur'an tidak diturunkan dalam ruang hampa, di dalamnya juga terdapat banyak informasi tentang mereka.

Kedua, menguasai secara menyeluruh seluk-beluk orangorang Arab dan sekitarnya sebagai sasaran utama turunnya alQur'an dari awal turunnya ayat pertama hingga ayat terakhir, bahkan hingga Rasulullah saw. wafat. Sebab tidak semua ayat alQur'an memiliki sababun nuzul sehingga bila hanya mengandalkan asbabun nuzul, maka penafsiran akan kurang sempurna. Oleh karenanya, penguasaan terhadap seluk-beluk orang-orang Arab dan sekitarnya sangat mendesak yang sangat diharapkan bisa membantu proses penafsiran kontekstual.

Ketiga, menyusun ayat-ayat al-Qur'an sesuai dengan kronologi turunnya, memperhatikan korelasi sawabiq dan lawahiq ayat, mencermati struktur lingustik ayat dan perkembangan penggunaannya dari masa ke masa, dan berusaha menggali kandungan inter-teks dan extra-teks secara komprehensif.

Kempat, mencermati penafsiran para tokoh besar awal Islam secara seksama dan konteks sosio-historinya, terutama yang secara lahir bertentangan dengan al-Qur'an, tetapi bila diperhatikan

21 Ahmad Harisuddin, "Urgensi Pendekatan Budaya dalam Pemahaman Al-Qur'an", dalam web: https://www.kompasiana.com/ banjarhulu/ urgensi-pendekatan-budaya-dalam-pemahamanalquran56794aa8c523bd2c0b29 dbdf, diakses pada tanggal 12 Desember 2017. 
ternyata sesuai dengan tuntutan sosial yang ada pada waktu itu dan tetap berada dalam spirit al-Qur'an.

Kelima, mencermati semua karya-karya tafsir yang ada dan memperhatikan konteks sosio-historis para penafsirnya. Sebab bagaimanapun juga, para penafsir mempunyai sisi-sisi kehidupan yang berbeda satu sama lain dan turut memengaruhi penafsirannya.

Keenam, menguasai seluk-beluk kehidupan manusia di mana al-Qur' an hendak ditafsirkan secara kontekstual dan perbedaan serta persamaannya dengan masa-masa sebelumnya, terutama pada masa awal Islam.

Dan yang terakhir, mengkombinasikan semua enam poin di atas dalam satu kesatuan utuh pada saat proses penafsiran dan tetap berpegang teguh pada prinsip-prinsip dasar al-Qur'an. ${ }^{22}$

Berikut adalah beberapa contoh aplikasi penafsiran kontekstual:

1. Poligami

Dalam al-Qur'an surat an-Nisa' yang kerap dikutip sebagai dalil untuk mengabsahkan praktik poligami adalah:

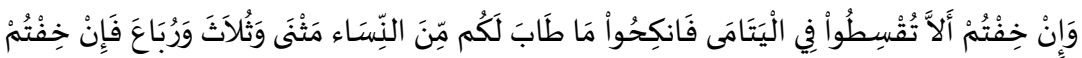

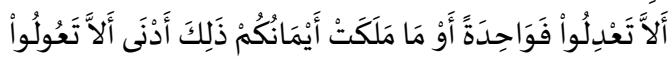

Dan jika kamu khawatir tidak akan mampu berlaku adil terhadap (hak-hak) perempuan yatim (bilamana kamu menikahinya), maka nikahilah perempuan (lain) yang kamu senangi: dua, tiga atau empat. Tetapi jika kamu khawatir tidak akan mampu berlaku adil, maka (nikahilah) seorang saja, atau hamba sahaya perempuan yang kamu miliki. Yang demikian itu lebih dekat agar kamu tidak berbuat zalim (An-Nisa': 3).

Sebagian besar ulama sepakat bahwa ayat ini merupakan dasar hukum dalam kebebasan berpoligami. Padahal, apabila ditelusuri sejarah bangsa arab pada zaman jahiliyah, mereka itu gemar berpoligami, sampai diantara mereka ada yang mempunyai istri sepuluh orang. Kemudian turun ayat al-Qur'an di atas untuk

${ }^{22}$ M. Subhan Zamzami, “Tafsir Kontekstual”, dalam http://msubhanzam zami.wordpress.com/2011/06/11/tafsir-kontekstual/ diakses pada tanggal tanggal 30 Oktober 2017. 
membatasi kepada mereka dengan empat orang saja. Itu pun bila mereka mampu berbuat adil. Yang diinginkan al-Qur'an sesungguhnya bukan praktek beristri banyak. Praktek ini tidak sesuai dengan harkat yang telah diberikan al-Qur'an kepada wanita. Status wanita yang selama ini cenderung dinomor duakan akan menjadi semakin kuat jika praktek poligami tetap diberlakukan. AlQur'an menyatakan bahwa laki-laki dan perempuan punya kedudukan dan hak yang sama. Maka pernyataan al-Qur'an bahwa laki-laki boleh punya istri sampai empat orang hendaknya dipahami dalam nuansa etisnya secara komprehensif. Ada syarat yang diajukan oleh al-Qur'an, yaitu menyangkut keadilan dalam rumah tangga.

\section{Perbudakan}

Sama dengan kasus poligami di atas, al-Qur'an pun mengakui secara hukum praktek perbudakan. Ini semata-mata dimaksudkan bersifat sementara dan ideal moralnya adalah pemerdekaan budak sebagaimana dalam Surat al-Balad ayat 12-13:

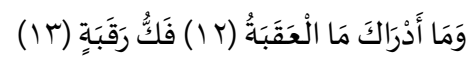

Dan tahukah kamu apakah jalan yang mendaki dan sukar itu? (Yaitu) melepaskan perbudakan (hamba sahaya).(QS. Al-Balad: 12-13).

Al-Qur'an secara tegas menyatakan bahwa bila seorang budak ingin menebus kemerdekaannya dengan membayar sejumlah uang cicilan yang ditentukan menurut kondisi sang budak, maka tuannya harus menyetujui perjanjian penebusan itu. Tuannya tidak boleh menolaknya, seperti yang ditegaskan al-Qur'an Surat An-Nur ayat 33:

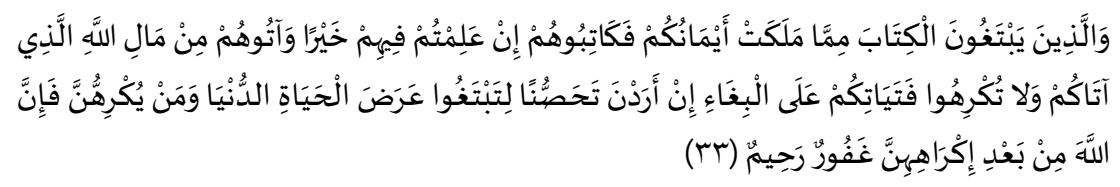

Dan budak-budak yang kamu miliki yang menginginkan perjanjian, hendaklah kamu buat Perjanjian dengan mereka, jika kamu mengetahui ada kebaikan pada mereka, dan berikanlah kepada mereka sebahagian dari harta Allah yang dikaruniakan-Nya kepadamu. Dan janganlah kamu paksa budak-budak wanitamu untuk melakukan pelacuran, sedang mereka sendiri mengingini kesucian, 
karena kamu hendak mencari Keuntungan duniawi. dan barangsiapa yang memaksa mereka, maka sesungguhnya Allah adalah Maha Pengampun lagi Maha P enyayang (kepada mereka) sesudah mereka dipaksa itu ( QS. An-Nur: 33).

Ayat di atas menurut Fazlur Rahman, al-Qur'an tidak diterapkan oleh umat Islam dalam sejarah. Kalimat al-Qur'an "Jika kamu mengetahui ada kebaikan pada mereka", bila dipahami dengan tepat akan berarti bahwa seorang budak yang dianggap belum mampu memperoleh penghasilan sendiri tidak bisa diharapkan dapat mandiri atau berdikari, dan karenanya mungkin lebih baik bila ia tetap berada dalam lindungan tuannya. Tapi sebaliknya, seorang budak yang sudah mampu berdikari, dan meminta kemerdekaannya dengan menebus segala syarat, maka tuannya harus memerdekakannya. Inilah ideal moral yang dituju alQur'an. ${ }^{23}$

3. Kepemimpinan Perempuan pada Wilayah Publik

Dalam sejarah sosiologis-kultural, pada saat itu perempuan cenderung diposisikan sebagai manusia kelas dua dari laki-laki, sehingga lahirlah persepsi hanya sekedar pelayan dan pelengkap. Hal ini bisa dilihat dari kedudukan perempuan pada masa Jahiliyah yang tidak mempunyai arti fundamental. Bahkan, kadang disamakan dengan barang yang bisa diwariskan kepada anakanaknya sendiri. Warisan ini diduga kuat mempengaruhi image terhadap distorsi kedudukan dan peran perempuan sampai saat ini dalam berbagai kehidupan publik termasuk wilayah politik yang dianggap sebagai wilayah kompotensi laki-laki. Subordinasi peran perempuan masih banyak terjadi, baik dalam kalangan keluarga maupun dalam kehidupan publik, khususnya wilayah politik. Sejumlah persepsi negatif dalam masyarakat yang ditautkan pada diri perempuan masih kuat, seperti perempuan sangat lemah, emosional, dan irrasional sehingga perannya hanya cocok dalam bidang domestik (mengurusi dapur, menata ranjang, dan mengurusi anak) dan tidak layak menjadi seorang pemimpin, bahkan tidak

23 Moh. Asep Widodo, "Pendekatan Tafsir Kontekstual”, dalam http://mohasepwidodo.blogspot.co.id/2013/01/pendekatan-tafsir-kontekstual. html diakses pada tanggal 12 Desember 2017. 
jarang persepsi ini dilegitimasi dengan merujuk dan menganggap sebagai pesan teologis. ${ }^{24}$

Dalil agama yang paling sering dirujuk untuk menguatkan argumen tersebut adalah Q.S. an-Nisa' ayat 34.

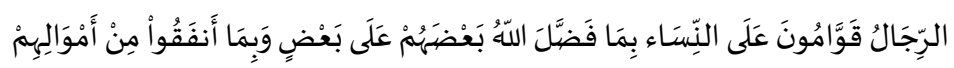

Laki-laki (suami) itu pelindung bagi perempuan (istri), karena Allah telah Melebihkan sebagian mereka (laki-laki) atas sebagian yang lain (perempuan), dan karena mereka (laki-laki) telah memberikan nafkah dari hartanya...

Umumnya, para mufassir klasik menyatakan bahwa "qawwamun" berarti pemimpin, pelindung, penanggung jawab. Selanjutnya mereka mengatakan bahwa kelebihan yang dimiliki kaum laki-laki atas kaum perempuan karena keunggulan akal dan fisiknya. Sebagai contoh, Imam al-Razi mengatakan bahwa kelebihan yang dimaksud dalam ayat di atas meliputi dua hal, yakni: ilmu pengetahuan dan kemampuan fisik. Akal dan pengetahuan laki-laki menurut al-Razi, melebihi akal dan pengetahuan perempuan. Demikian pula halnya, laki-lakiunggul dalam pekerjaan keras.

Penafsiran kata "qawwamun” dengan pemimpin juga mewarnai khazanah penafsiran di Indonesia. Hamka misalnya, menafsirkannya sebagai pemimpin. Dalam hubungannya dengan pembagian harta warisan dua (untuk laki-laki) banding satu (untuk perempuan), ia mengemukakan argumentasi bahwa konsekuensi tersebut karena laki-laki harus membayar mahar dan memberikan nafkan kepada istrinya, dan menggaulinya dengan baik.

Jika dilakukan pembacaan ulang secara komprehensif, maka tampak bahwa penafsiran seperti tersebut di atas tidak tepat lagi untuk dipertahankan. Sebab, jika ditelaah sababun nuzul ayat di atas, ternyata hanya berkaitan dengan persoalan rumah tangga, sehingga tidak tepat jika digeneralisir dalam semua wilayah kepemimpinan. Penafsiran yang lebih adil diberikan oleh

${ }^{24}$ Tasbih, "Urgensi Pemahaman Kontekstual Hadis (Refleksi terhadap Wacana Islam Nusantara), dalam jurnal Al-Ulum, Vol. 16, No. 1, Juni 2016, 95 96 
Muhammad Jawad Mughniyah yang mengatakan bahwa ayat diatas hanya ditujukan kepada laki-laki sebagai suami dan perempuan sebagai isteri. Keduanya adalah rukun kehidupan. Tidak satupun di antara keduanya bisa hidup tanpa yang lain, dan keduanya saling melengkapi.

Aspek lain harus dipertimbangkan pula bahwa bentuk kepemimpinan masa lampau adalah kepemimpinan personal. Semua urusan diserahkan pada satu sosok pemimpin. Karena itu, jika sosoknya lemah, maka wajarlah jika tidak direkomendasikan untuk menjadi pemimpin. Kini, pola kepemimpinan lebih bersifat kolektifsistemik. Oleh sebab itu, kekurangan yang dimiliki oleh seorang pemimpin --laki-laki sekalipun-- dapat disimbiosiskan dengan perangkat kepemimpinan lainnya, misalnya lembaga legislatif dan lembaga yudikatif. Bahkan, kata Amin Abdullah, kemampuan dan kelebihan yang dulunya hanya dimiliki oleh lakilaki karena kekuatan ototnya, kini dapat digantikan dengan kecanggihan teknologi. ${ }^{25}$

Pemaparan bukti-bukti penafsiran kontekstual para tokoh awal Islam di atas kurang sempurna bila belum dilengkapi dengan pemaparan penafsiran kontekstual para sarjana tafsir generasi setelah mereka. Dalam hal ini, penafsiran kontekstual at-Thabari (224-310 H.) dan Muhammad Rasyid Ridha (1865-1935) juga perlu dielaborasi. Tokoh pertama dikenal sebagai sarjana tafsir ulung klasik yang karya tafsirnya Jami' al-Bayan 'an Ta'wil Ayi alQur'an diakui secara luas sebagai induk dan rujukan utama tafsir bi al-ma'tsur dan mewakili tafsir-tafsir klasik. Sementara itu, tokoh kedua dikenal sebagai sarjana tafsir modern-kontemporer yang berpengaruh besar dalam pemikiran Islam dewasa ini dan karya tafsirnya Tafsir al-Manar mendapatkan apresiasi luar biasa sehingga cukup mewakili tafsir-tafsir modern-kontemporer. ${ }^{26}$

${ }^{25}$ Ahmad Faisal, "Tafsir Kontekstual Berwawasan Gender (Eksplorasi, Kritik dan Rekonstruksi)”, 476-479.

${ }^{26}$ Zulyadin, "Menimbang Kontroversi Pemaknaan Konsep Ahl Al-Kitab dalam Al-Qur'an”, Dalam jurnal Ulumuna: Jurnal Studi Keislaman, Vol. 16, No. 2, Desember 2012, 294. 
4. Al-Khabīiat dan at-Thayyibat

At-Thabari mempunyai penafsiran kontekstual seperti dalam penafsirannya terhadap ayat 26 surat an-Nur tentang makna al-Khabitsat dan at-Thayyibat. Sebelum menafsirkannya, ia mengutarakan dua penafsiran para sarjana Muslim yang berbeda tentang makna dua kata ini. Penafsiran pertama, perkataanperkataan jelek adalah milik kaum laki-laki jelek dan perkataanperkataan baik adalah milik orang yang baik. Ini adalah penafsiran Ibnu 'Abbas, Mujahid, ad-Dahhak, Sa'id ibn Jubair, Qatadah, dan Atha'. Penafsiran kedua, para wanita jelek adalah milik para lakilaki jelek dan para wanita baik adalah milik para laki-laki yang baik. Ini adalah penafsiran Ibnu Zaid. At-Thabari memilih pendapat pertama dengan argumentasi bahwa ayat-ayat sebelumnya mencela kaum munafik yang berbicara kotor dan menuduh Ummul Mu'minin A'isyah RA, dan ayat ini sebagai penutup tentang orangorang jelek yang berbicara kotor itu. Argumentasinya menunjukkan ia memperhatikan sabab al-nuzul ayat ini dan hubungannya dengan ayat-ayat sebelumnya. Dengan kata lain, ia menafsirkannya sesuai konteks turunnya ayat tersebut. ${ }^{27}$

\section{Ahli Kitab}

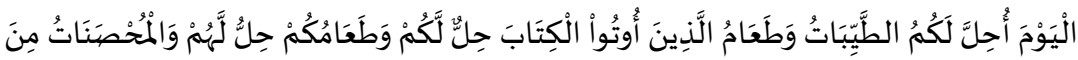

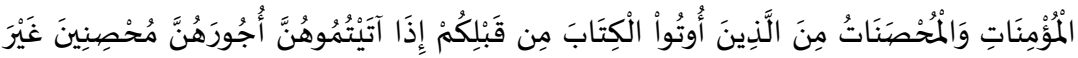

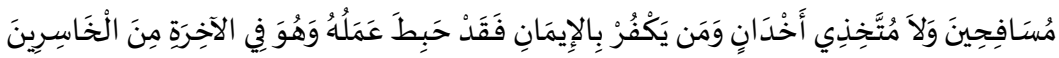

Pada hari ini dihalalkan bagimu segala yang baik-baik. Makanan (sembelihan) ahli kitab itu halal bagimu, dan makananmu halal bagi mereka. Dan (dihalalkan bagimu menikahi) perempuan-perempuan yang menjaga kehormatan di antara perempuan-perempuan yang beriman dan perempuan-perempuan yang menjaga kehormatan di antara orang-orang yang diberi kitab sebelum kamu, apabila kamu membayar maskawin mereka untuk menikahinya, tidak dengan maksud berzina dan bukan untuk menjadikan perempuan piaraan. Barangsiapa kafir setelah beriman maka sungguh, sia-sia amal mereka dan di akhirat dia termasuk orang-orang yang rugi. (QS. AlMaidah: 5).

${ }^{27}$ M. Subhan Zamzami, “Tafsir Kontekstual, dalam http://msubhanzam zami.wordpress.com/2011/06/11/ tafsir-kontekstual/, diakses pada tanggal 12 Desember 2017 
Menyikapi surat ini, Muhammad Rasyid Ridha mempunyai penafsiran kontekstual menarik tentang konsep Ahli Kitab. Ia berpendapat bahwa al-Qur'an menyebut para penganut agamaagama terdahulu, kaum Sabi'in dan Majusi, dan tidak menyebut kaum Brahma (Hindu), Budha, dan para pengikut Konfusius karena kaum Sabi'in dan Majusi dikenal oleh bangsa Arab, yang menjadi sasaran awal al-Qur'an, itu berada berdekatan dengan mereka di Irak dan Bahrain. Tujuan ayat suci telah tercapai dengan menyebutkan agama-agama yang dikenal (oleh bangsa Arab), sehingga tidak perlu membuat keterangan yang terasa asing dengan menyebut golongan yang tidak dikenal oleh orang yang menjadi alamat pembicaraan itu di masa turunnya al-Qur'an, berupa penganut agama-agama yang lain. Setelah itu tidak diragukan lagi bagi mereka (orang Arab) yang menjadi alamat pembicaraan (wahyu) itu bahwa Allah juga akan membuat keputusan perkara antara kaum Brahma, Budha, dan lain-lain.

Pendapat ulama besar ini, merupakan hasil penilaiannya secara panjang lebar riwayat-riwayat yang dikemukakan oleh para sahabat Nabi dan tabi'in, kaidah-kaidah ushul dan kebahasaan serta menyimak dan menimbang pendapat para ulama sebelumnya, sehingga beliau menyimpulkan dalam fatwanya sebagaimana dikutip oleh M. Quraish Shihab sebagai berikut:

$$
\begin{aligned}
& \text { وملخص هذه الفتوى أن المشركات اللآتي حرم الله نكاحهن فى آية البقرة هن مشركات العرب وهو المشا }
\end{aligned}
$$

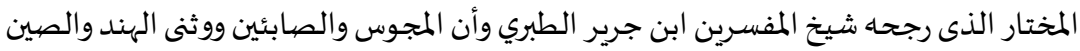

$$
\begin{aligned}
& \text { وأمثالهم كاليابانيين أهل كتب مشتملة على التوحيد إلى الآن. }
\end{aligned}
$$

"Kesimpulan fatwa ini adalah bahwa laki-laki Muslim yang diharamkan oleh Allah menikah dengan wanita-wanita musyrik dalam surat al-Baqarah ayat 221 adalah wanita-wanita musyrik Arab. Itulah pilihan yang dikuatkan oleh Mahaguru para mufassir Ibnu Jarir at-Thabari, dan bahwa orang-orang Majusi, al-Shābi'īn, penyembah berhala di India, Cina, dan yang semacam mereka seperti orangorang Jepang adalah ahl al-kitäb yang (kitab mereka) mengandung ajaran tauhid sampai sekarang."

Pernyataan Muhammad Rasyid Ridha ini merupakan penafsiran kontekstualnya terhadap konsep Ahli Kitab yang selama ini mayoritas sarjana Sunni membatasinya hanya pada Yahudi dan 
Kristen. Menurutnya, konsep Ahli Kitab juga mencakup Hindu, Budha, dan para pengikut Konfusius karena pada saat turunnya alQur'an orang Arab belum mengenal agama-agama tersebut sehingga tidak perlu menyebutnya. Secara tidak langsung, ia mengakui adanya sisi-sisi lokalitas-temporal al-Qur'an yang memerlukan pemahaman dan wawasan mendalam untuk menafsirkannya seperti konsep Ahli Kitab, sehingga seorang penafsir tidak terjebak dalam sisi-sisi lokalitas-temporalnya dan berusaha mengungkapkan maksud kandungan internal dan eksternalnya sesuai dengan konteks di mana ia diturunkan dan ditafsirkan guna merespons tuntutan kehidupan aktual manusia. ${ }^{28}$

\section{J. Apresiasi dan Kritik Terhadap Tafsir Kontekstual}

Tafsir keagamaan yang kontekstual telah menarik perhatian banyak ulama dan cendikiawan muslim untuk mengembangkannya menurut versi masing-masing. Hal itu antara lain disebabkan karena:

Pertama, tafsir kontekstual dinilai lebih mampu merespon masalah-masalah sosial kemanusiaan yang terus berkembang

Alasan kedua yang menyebabkan tafsir kontekstual mendapat banyak perhatian, karena dinilai lebih responsif dalam menangani masalah secara kongkrit. Hal tersebut karena tafsir kontekstual dibangun berdasarkan pertimbangansitusasi yang konkrit, dan bukan atas argumen ideologis dan teologis

Alasan ketiga, tafsir keagamaan yang kontekstual dinilai lebih mampu berdialog dengan dinamika kehidupan, rasionalitas dan alam pikiran masyarakat modern Dengan pola pikir demikian, kaum muslimin dapat berdampingan dan merespon secara kritiskonstruktif berbagai permasalahan kemanusiaan. ${ }^{29}$

Meskipun tampak dapat menjawab banyak problem umat, tafsir kontekstual juga mengundang sejumlah kritik atas kelemahannya, diantaranya sebagai berikut:

${ }^{28}$ Zulyadain, "Menimbang Kontroversi Pemaknaan Konsep Ahl AlKitab dalam Al-Qur'an”, 301-303.

29 Ahmad Faisal, "Tafsir Kontekstual Berwawasan Gender (Eksplorasi, Kritik dan Rekonstruksi)”, 476-482. 
Pertama, fakta bahwa tidak semua ayat al-Qur'an mempunyai sabab an-nuzul bahkan sebagian besar ayat tidak memilikinya. Padahal asbab an-nuzul merupakan tonggak utama tafsir kontekstual.

Kritik kedua, rumitnya menguasai seluruh aspek kehidupan manusia sejak pra-Islam hingga sekarang. Padahal asbab an-nuzul yang sedikit bisa disempurnakan dengan penguasaan terhadap seluruh aspek kehidupan mereka ini.

Kritik ketiga, tafsir kontekstual tidak berlaku pada ayat-ayat al-Qur'an yang berbau akidah.

Kritik keempat, tafsir kontekstual cenderung berlaku pada waktu dan masa tertentu, tidak berlaku secara universal dan sepanjang masa.

Kritik terakhir, perubahan kehidupan manusia yang serba cepat menuntut penafsiran kontekstual yang juga cepat. Padahal penafsiran yang tergesa-gesa sangat berpotensi untuk keliru. ${ }^{30}$

\section{K. Penutup}

Dalam mengajarkan Islam, pada dasarnya berdasarkan dua sumber fundamental, yaitu al-Qur'an dan tradisi Nabi. Al-Qur'an petunjuk hidup yang bersifat holistik, komprehensif, luas dan mendalam berfungsi mendasari dan menuntun berbagai dimensi kehidupan manusia menuju keridhaan Allah SWT.

Al-Qur'an merupakan perkataan dari Tuhan dan kehadiran Ilahi pada ruang dan waktu sejarah. Melalui penyelidikan terhadap interpretasi sejarah berdasarkan aspek linguistik dalam al-Qur'an, sebuah usaha dilakukan untuk meningkatkan definisi yang jelas mengenai tafsir dan bagaimana al-Qur'an itu diinterpretasikan dalam sejarah Islam. Teks al-Qur'an sendiri sangat debatable, bahkan multi interpretatif. Para pembacanya selalu saja ingin mengutip dan menafsirkan, karena itu lahirlah berbagai komentar, beragam buku, dan juga beragam sanjungan dan hujatan. Pada saat

30 Iffah Muzammil, "Tafsir Kontekstual, dalam web: http://iffahmuzammil.blogspot.co.id/2014/11/tafsirkon tekstual.html, diakses pada tanggal 13 Desember 2017. 
yang sama, di ujung sudut yang lain selalu saja ada keinginan untuk kembali dan berlindung di bawah naungannya.

Tafsir kontekstual adalah kegiatan untuk mengeksplansi firman Allah SWT dengan memperhatikan indikasi-indikasi dari susunan bahasa dan keterkaitan kata demi katayang tersusun dalam kalimat serta memperhatikan pula penggunaan susunan bahasa itu oleh masyarakat, sesuai dengan dimensi ruang dan waktu. Sehingga tafsir jenis ii memiliki aneka ragam konteks, baik konteks bahasa, konteks waktu, konteks tempat, maupun konteks sosial budaya. Di antara ciri penafsiran kontekstual adalah model tafsir ini menekankan konteks sosio-historis dalam proses penafsirannya. Ciri lainnya, tafsir ini lebih melihat nilai etis dari ketetapan legal (the ethico-legal content) al-Qur'an, daripada makna literalnya. [ ] 


\section{DAFTAR PUSTAKA}

Saeed, Abdullah, "Al-Qur'an Abad 21 Tafsir Kontekstual”, Bandung: Mizan Pustaka, 2016.

, "Pengantar Studi Al-Qur'an”, terjemahan Shulkhah dan Sahiron Syamsuddin, Yogyakarta: Baitul Hikmah Press. 2016.

Zaini, Achmad, "Model Interpretasi Al-Qur'an Abdullah Seed", dalam jurnal Islamica, Volume: 6, Nomor: 1, September 2011.

Faisal, Ahmad, "Tafsir Kontekstual Berwawasan Gender (Eksplorasi, Kritik dan Rekonstruksi)", dalam jurnal AlUlum: Jurnal Studi-Studi Islam, Volume: 13 Nomor: 2, Desember 2013.

Ansyory, Anhar, "Pengantar Ulumul Qur'an", Yogyakarta: Lembaga Pengembangan Studi Islam Universitas Ahmad Dahlan Yogyakarta, 2012.

Buwaihi, "Fazlur Rahman dan Pembaharuan Metodologi Tafsir AlQuran", dalam jurnal Media Akademika, Volume: 28, Nomor: 1, Januari 2013.

Surahman, Cucu, "Tafsir Kontekstual JIL: Telaahatas Konsep Syariat Islam dan Hudud", dalam Journal of Qur'an and Hadith Studies, Volume: 2, Nomor: 1, 2012.

Miski, “Hermeneutika Al-Qur'an Kontemporer: Telaah Atas Hermeneutika MuhAmmad Al-Gazali Dalam Nahw Tafsir Maudu'i liSuwar al-Qur'an al-Karim”, dalam jurnal Hermeneutik, Volume: 9, Nomor: 2, Desember 2015.

Ridwan, Mk., "Tradisi Kritik Tafsir: Diskursus Kritisisme Penafsiran dalam Wacana Qur'anic Studies”, dalam jurnal Theologia, Volume: 28, Nomor:1, Juni 2017.

Mustaqimah, "Urgensi Tafsir Kontekstual dalam Penafsiran AlQur'an", dalam jurnal Farabi, Volume: 12, Nomor: 1, Juni 2015. 
Affandy, Sa'dullah, "Menyoal Status Agama-agama Pra-Islam”, Bandung: PT. Mizan Pustaka, 2015.

Rosa, Mohammad Andi, "Prinsip Dasar dan Ragam Penafsiran Kontekstual”, dalam Jurnal Holistic Al-Hadis, Volume: 1, Nomor: 2, Juli-Desember 2015.

Syahrullah, "Tarjamah Tafsiriah Terhadap Al-Qur'an: Antara Kontekstualisasi dan Distorsi”, dalam Journal of Qur'an and Hadith Studies, Volume: 2, Nomor: 1, 2013.

Siregar, Ferry Muhammadsyah, "Exploring Methodological Aspect of Linguistic in the Qur'an and its Tafsir" dalam jurnal Religia, Volume: 15, Nomor: 1, April 2012.

Suryadilaga, Muhammad Alfatih, "Hadis dan Perannya dalam Tafsir Kontekstual Perspektif Abdullah Saeed", dalam Jurnal Mutawatir: Jurnal Keilmuan Tafsir Hadis, Volume: 5, Nomor: 2, Desember 2015.

, "Kontekstualisasi Hadis dalam Kehidupan Berbangsa dan Berbudaya", dalam Jurnal Kalam, Volume: 11, Nomor: 1, Juni 2017.

Tasbih, "Urgensi Pemahaman Kontekstual Hadis (Refleksi terhadap Wacana Islam Nusantara), dalam jurnal Al-Ulum, Volume: 16, Nomor: 1, Juni 2016.

Zulyadain, "Menimbang Kontroversi Pemaknaan Konsep Ahl AlKitab dalam Al-Qur'an”, Dalam jurnal Ulumuna: Jurnal Studi Keislaman, Volume: 16, Nomor: 2, Desember 2012.

http://msubhanzamzami.wordpress.com/2012/06/11/tafsir-kontekstual/, diakses pada 30 Oktober 2017.

http://www.pesantrenalirsyad.org/urgensi-tafsir-dalam-memahamial-Qur'an/, diakses pada 12 Desember 2017.

https: //www.kompasiana.com/banjarhulu/urgensi-pendekatanbudaya-dalam-pemahaman-alquran56794aa8c523bd2c0b29 dbdf, diakses pada tanggal 12 Desember 2017.

http: //mohasepwidodo. blogspot.co.id/2013/01/pendekatan-tafsirkontekstual.html, diakses pada tanggal 12 Desember 2017. 
http://iffahmuzammil.blogspot.co.id/2014/11/tafsirkon tekstual. html, diakses pada tanggal 13 Desember 2017.

http://download.portalgaruda.org/article.php?article=116305\&val= 5267, diakses pada tanggal 14 Desember 2017. 